\title{
A 150-year record of recent changes in human activity and eutrophication of Lake Wushan from the middle reach of the Yangze River, China
}

\author{
Enlou ZHANG*, Enfeng LIU, Richard JONES ${ }^{1)}$, Peter LANGDON²), Xiangdong YANG and Ji SHEN \\ State Key Laboratory of Lake Science and Environment, Nanjing Institute of Geography \& Limnology, Chinese Academy of \\ Sciences, China 210008 \\ ${ }^{1)}$ Department of Geography, University of Exeter, EX4 4QJ Exeter, U.K. \\ ${ }^{2)}$ School of Geography, University of Southampton, SO17 1BJ Southampton, U.K. \\ *e-mail corresponding author: elzhang@niglas.ac.cn
}

\begin{abstract}
In order to determine baseline conditions (pre-impact) and recent changes to lakes on the middle reach of the Yangtze River, China, a lake sediment core was extracted from Lake Wushan covering the last ca 150 years. Detailed chemical, biological (subfossil chironomids), and physical analyses of the lake sediments were undertaken. The data showed consistent trends of increased productivity since the early 1920s, notably significant changes in the chironomid fauna which were associated with changes in the sedimentological and stable isotope proxies. More typically eutrophic chironomid taxa first appeared around this time that had not been present in the lake since at least the 1860s. Further increases in productivity occurred around the 1950s which coincided with the local decline and extirpation of some chironomid taxa, particularly macrophyte associated taxa, which had been present in the lake since at least the late $19^{\text {th }}$ Century. A chironomid-inferred water total phosphorus (CI-TP) reconstruction produced accurate levels of water TP compared with contemporary measurements $\left(207.4 \mu \mathrm{g} \mathrm{L^{-1 }} T P\right)$, and suggested that levels for the late $19^{\text {th }}$ Century were relatively low (50-60 $\left.\mu \mathrm{g} \mathrm{L}^{-1} \mathrm{TP}\right)$. These reconstructions illustrate the baseline levels that existed pre-impact and provide potential targets for restoration, but they also show the magnitude of human impact in this region, which has increased the nutrient content of Lake Wushan fourfold within the last ca 100 years.
\end{abstract}

Key words: lake sediment, eutrophication, human activity, stable isotopes, subfossil chironomids

\section{INTRODUCTION}

The deteriorating quality of terrestrial freshwater sources has been one of the largest and most widespread environmental problems in the world, especially in developing countries such as China (Liu \& Diamond 2005). Eutrophication is a particularly severe problem for lakes in the middle and lower reaches of the Yangtze River, China (Qin \& Zhu 2006). Formalized efforts to halt or reverse the rate of eutrophication have been established across the Lower Yangtze region. Targets for each site have been established based on pre-disturbance baseline conditions defined using nutrient load models driven by palaeolimnological datasets (e.g., Hall \& Smol 1999; Jordan et al. 2001; Smol 2002; Ramstack et al. 2004). For regionally unique and highly altered systems, the approach of using the palaeolimnological record to define 'pre-disturbance' conditions is often the most reliable (Engstrom et al. 2006).

Lake Wushan is located in the middle reach of the Yangtze River and has a complex and highly altered hydrological system. The lake-catchment system has been heavily affected by both agricultural and industrial activity and widespread urbanization, the combined impact of which has led to a marked decline in water quality reflected by increased eutrophication of the lake. There is no long-term water quality data for the site and as such it is unknown what is driving these changes, how fast they occurred or at what point in time the system began to change. Defining the nature of the pre-impact limnological system is therefore impossible using current datasets. To address these issues a multi-proxy palaeolimnological study of the recent sediments was undertaken the results of which are outlined in this paper.

\section{METHODS}

\subsection{Site description}

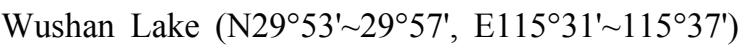
is a hypereutrophic lake in the middle part of the Yangtze floodplain (Fig. 1). Its surface area was decreased from $42.5 \mathrm{~km}^{2}$ to the present $16.1 \mathrm{~km}^{2}$ because of land reclamation programmes during 1950-70s (Wang \& Dou 1998). The lake has a maximum depth of $4.7 \mathrm{~m}$ and a mean depth of $3.1 \mathrm{~m}$. The lake has a drainage area of $469.0 \mathrm{~km}^{2}$, with inflows from the northern hillocks and it drains into Taibai Lake to the East. Presently there are no macrophytes in the open water (Jian et al. 2001). Water quality investigations in July 2001-April 2003 indicated that the annual average TP concentration was high $\left(207.4 \mu \mathrm{g} \mathrm{L}^{-1}\right)$, suggesting that the lake is now hypereutrophic (Yang et al. 2008). Since 1987 the establishment of several chemical factories on the lakeside has led to increased pollution of the lake (Jian et al. 2001), speeding up the eutrophication process and the 

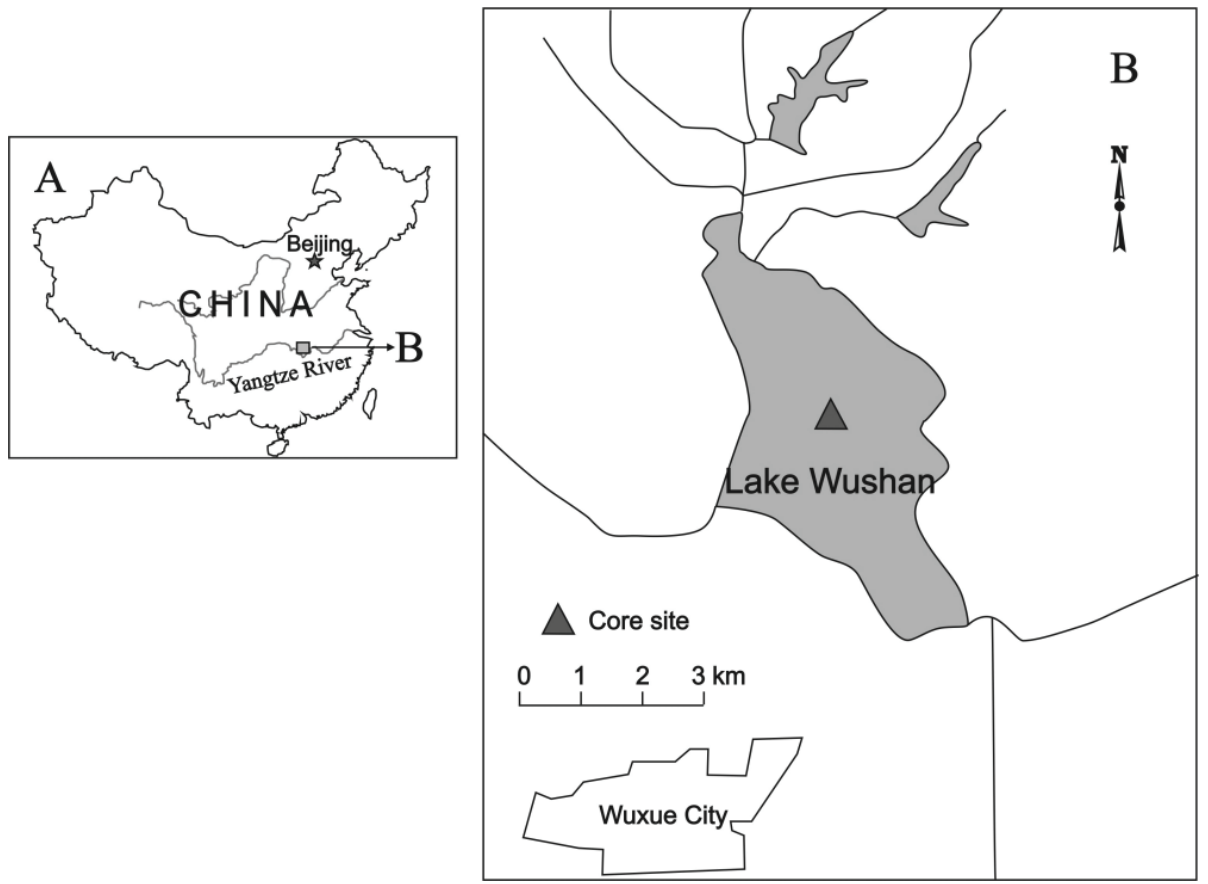

Fig. 1. Map of Lake Wushan and the location of sampling site.

deterioration of the lake ecosystem (Wuxue committee for compilation of local chronicles, 1994). This situation was exacerbated even further with the introduction of commercial fish stocking in the lake at this time (Jian et al. 2001; Yang et al. 2002).

\subsection{Coring and subsampling}

In April 2007, a 50-cm sediment core was collected from the centre of Wushan Lake (water depth: $4 \mathrm{~m}$ ) using a Kajak gravity corer with a 60 -mm-diameter coring tube. The sediment core was sub-sampled at 1 $\mathrm{cm}$ contiguous intervals and refrigerated at $4{ }^{\circ} \mathrm{C}$ prior to analysis.

\subsection{Chronology}

Sediment samples were dated using ${ }^{210} \mathrm{~Pb}$ and ${ }^{137} \mathrm{Cs}$ by non-destructive gamma spectrometry (Appleby \& Oldfield 1992). Samples were counted on an Ortec HPGe GWL series well-type coaxial low background intrinsic germanium detector to determine the activities of ${ }^{210} \mathrm{~Pb},{ }^{226} \mathrm{Ra}$ and ${ }^{137} \mathrm{Cs}$. Sediment chronologies were calculated using a composite model (Appleby 2001). ${ }^{137} \mathrm{Cs}$ was used to identify the 1963 nuclear weapons peak, which was then used as part of a constant rate of supply (CRS) model to calculate ${ }^{210} \mathrm{~Pb}$ chronology for the core. The CRS model was chosen due to the complexity and heavily impacted nature of the hydrological system at Wushan.

\subsection{TOC, TN, $\delta^{13} C$ and $\delta^{15} N$}

Bulk carbon samples were prepared for contiguous 1 $\mathrm{cm}$ samples, which were prepared by placing $2 \mathrm{~g}$ of wet sediment overnight in $50 \mathrm{~mL}$ of $5 \%$ hydrochloric acid to remove carbonates. The samples were then washed with deionised water, oven dried at $40{ }^{\circ} \mathrm{C}$, ground into a fine powder and sieved at $80 \mu \mathrm{m}$. TOC and TN analyses were performed by combustion using a FlashEA1112 Elemental Analyser linked to a Thermo Deltalus Advantage mass spectrometer. $\delta^{13} \mathrm{C}$ values were calculated to the VPDB scale and $\delta^{15} \mathrm{~N}$ calculated to the AIR scale. Analytical precision was $0.1 \%$ for organic carbon and $0.15 \%$ for nitrogen isotope ratios. TOC and TN were determined by reference to standard samples, and replicate analyses of well-mixed samples indicate a precision of $\pm 0.1 \%$ ( $1 \mathrm{SD}$ ).

\subsection{Sediment phosphorus species}

The chemical speciation of phosphorus in the sediment was determined following the SMT protocol (Ruban et al. 2001). This operationally defined sequential extraction scheme defined the Phosphorus into three species; $\mathrm{NaOH}$-extractable $\mathrm{P}$ ( $\mathrm{NaOH}-\mathrm{P}, \mathrm{P}$ bound to $\mathrm{Al}$, $\mathrm{Fe}$ and $\mathrm{Mn}$ oxides and hydroxides), $\mathrm{HCl}$-extractable $\mathrm{P}$ (HCl-P, Ca-bound P) and organic P (OP). The sum of these was then expressed as TP. During the sequential extraction analysis, parallel samples were analysed for accuracy control. The maximum relative standard deviation was lower than $10 \%$.

\subsection{Magnetic susceptibility}

Freeze dried sub-samples were packed into prescreened $10 \mathrm{~mL}$ polystyrene sample pots and the analysed using a dual frequency $(470 \mathrm{~Hz}=\chi \mathrm{LF}, 4700 \mathrm{~Hz}$ $=\chi \mathrm{HF}$ ) Bartington Instruments MS2 sensor (e.g., Evans \& Heller 2003). 


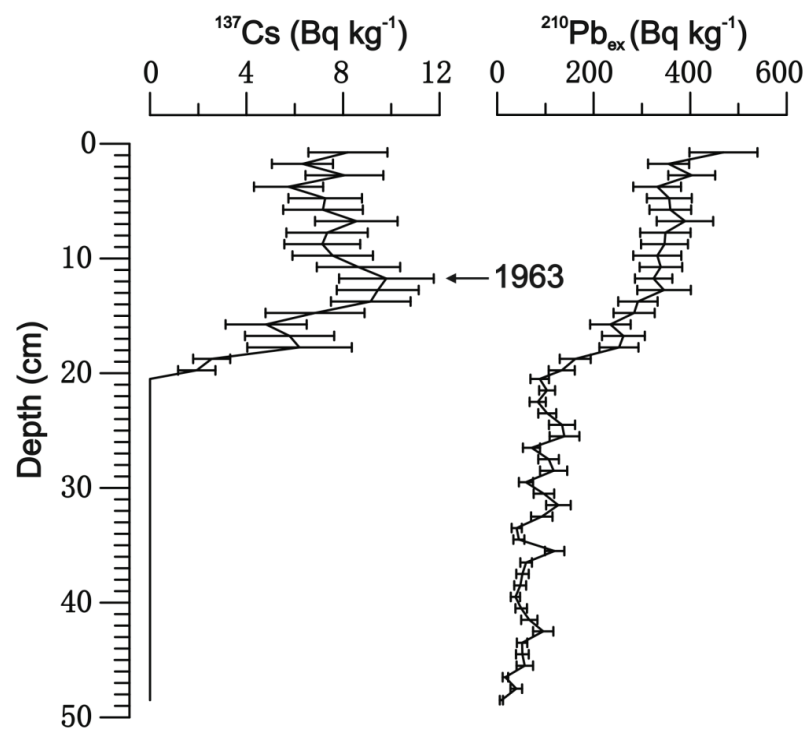

Fig. 2. Variation of ${ }^{137} \mathrm{Cs}$ and ${ }^{210} \mathrm{~Pb}$ activities in the core sediment of Lake Wushan.

\subsection{Subfossil chironomid analysis and lake water TP reconstruction}

Sediment samples were analysed for chironomids by following standard methods (Brooks et al. 2007). Deflocculate sediments in $10 \% \mathrm{KOH}$ in water bath at 75 ${ }^{\circ} \mathrm{C}$ for 15 minutes. The samples were then sieved with $212 \mu \mathrm{m}$ and $90 \mu \mathrm{m}$ meshes and the residue was examined under a stereo-zoom microscope at $25 \times$. All the head capsules found were mounted on microscope slides in a solution of Hydromatrix ${ }^{\circledR}$. The chironomid head capsules were identified mainly following Oliver \& Roussel (1983), Wiederholm (1983), Rieradevall \& Brooks (2001), and Brooks et al. (2007).

Lake water TP for the Wushan Core was calculated using a chironomid-TP inference model by applying an optimal two-component WA-PLS model which provides a high jack-knifed coefficient of prediction for conductivity $r_{\text {jack }}^{2}=0.76$, with a low root mean squared error of prediction $\left(\mathrm{RMSEP}_{\text {jack }}=0.13\right)$ (Zhang et al. 2006). The water TP reconstruction was undertaken using the program C2 (Juggins 2003). Minimum variance cluster analysis was performed using CONISS (Grimm 1987), implemented by the programs TILIA and TILIGRAPH (Grimm 1991) to identify the major zones in species composition.

\section{RESULTS}

\subsection{Chronology and mass accumulation rate}

The 1963 spike in ${ }^{137} \mathrm{Cs}$ associated with the peak in atmospheric nuclear weapons testing (Appleby 2001) is clearly evident in the core at $12 \mathrm{~cm}$ (Fig. 2). The ${ }^{210} \mathrm{~Pb}_{\mathrm{exc}}$ profile shows a continuous increase from the bottom to the top of the core, but no exponential distribution (Fig. 2). When compared to the $1963{ }^{137} \mathrm{Cs}$ speak, the ${ }^{210} \mathrm{~Pb}$ data was found to be too old, reflecting a decrease in sedimentation rates linked to reservoir construction in the upper reaches of Wushan lakes catchment during the early 1960s. The ${ }^{137} \mathrm{Cs}$ data was therefore used to constrain the ${ }^{210} \mathrm{~Pb}$ data and produce a composite age model. Calculated mass accumulation rates (MAR) are seen to vary markedly over the last 150 years (Fig. 3). From 1860 s to the mid $20^{\text {th }}$ Century, they rise rapidly peaking in the early 1950 s after which point they decline through to the top of the core.

\subsection{TOC, TN, $C / N, \delta^{13} C$ and $\delta^{15} N$}

TOC is seen to decline from $c a 6 \%$ to $1 \%$ between the years 1860s and the middle 1920s (Fig. 4). From the middle 1920 s to the present day the values increased steadily to $\mathrm{ca} 3 \%$. The TN curve produces a similar trend as TOC but with lower values, which decreased from $\mathrm{ca} 0.4 \%$ to $0.1 \%$ between $1860 \mathrm{~s}$ and the middle $1920 \mathrm{~s}$, and increased again to present day value ( $c a$ $0.4 \%)$. $\mathrm{C} / \mathrm{N}$ ratios were calculated to examine the relative importance of autochthonous and allochthonous sources of organic material within the Lake Wushan sediments (Meyers 1994; Meyers and Teranes 2001). $\mathrm{C} / \mathrm{N}$ ratios vary between 10 and 12 before the early 1900s (38 cm depth), after which point they decreased gradually to 8 .

$\delta^{15} \mathrm{~N}$ values for the core were generally low, but values increasing steadily until the early 1920 s, after which point they plateau. Following this stable period until the middle $1950 \mathrm{~s}, \delta^{15} \mathrm{~N}$ increased through to the present day. In contrast $\delta^{13} \mathrm{C}$ values oscillated between 1860 s and the middle 1920s on a decreasing trend before stabilizing from the middle 1920s to the 1940s. From the 1940s through to the middle 1950s values decreased again after which point they stabilized through to the top of the core. 


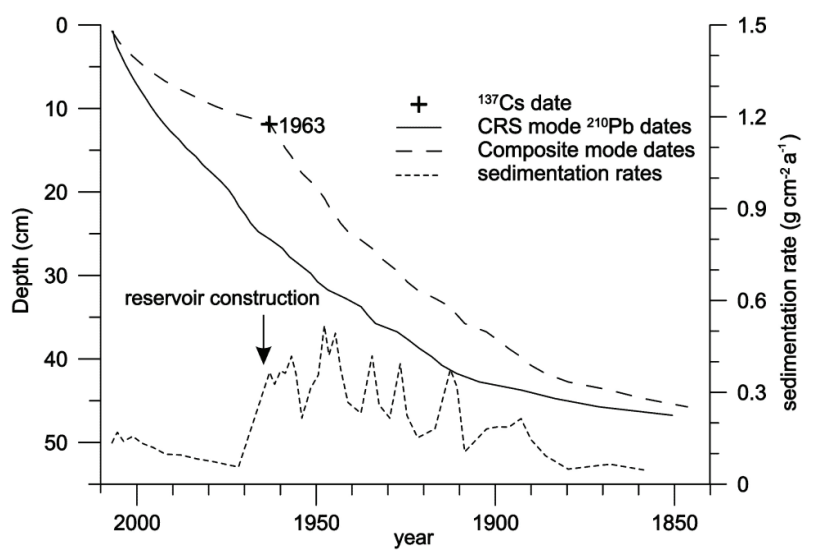

Fig. 3. Chronology and sedimentation rate of Lake Wushan.

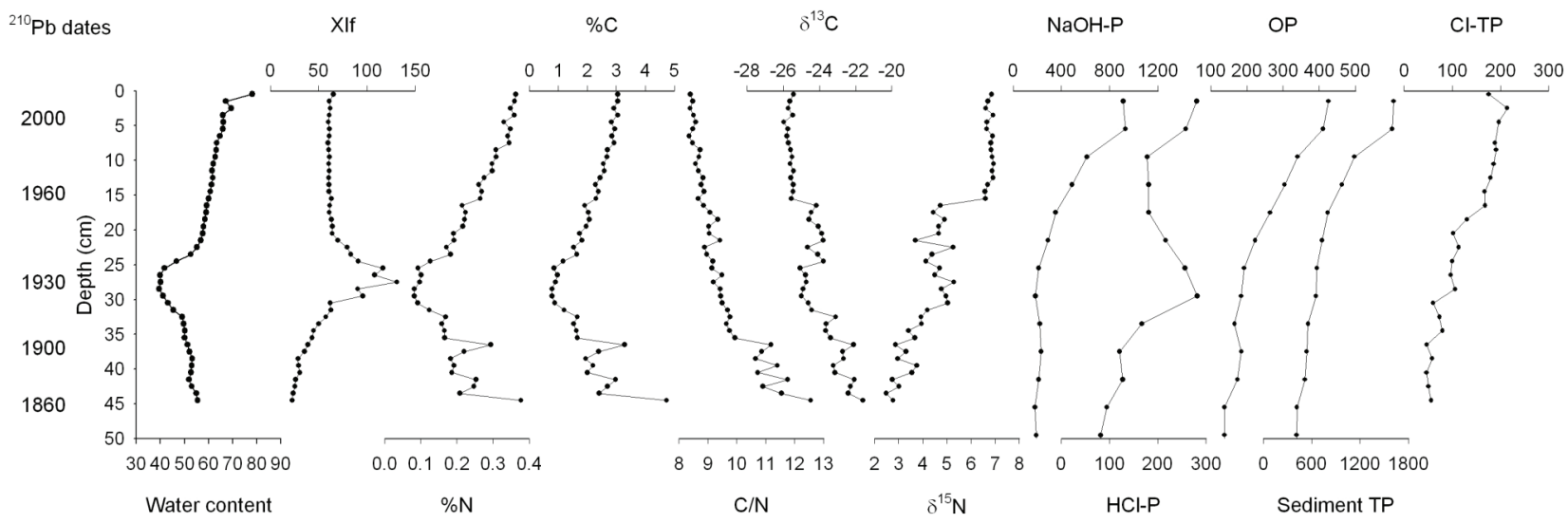

Fig. 4. Depth profiles of the geochemical proxies (water content (\%), $\chi \mathrm{LF}\left(10^{-8} \mathrm{~m}^{3} \mathrm{~kg}^{-1}\right), \mathrm{TN}(\%), \mathrm{TOC}(\%), \mathrm{C} / \mathrm{N}, \delta^{13} \mathrm{C}(\%$ vs VPDB), $\delta^{15} \mathrm{~N}\left(\%\right.$ vs air $\left.\mathrm{N}_{2}\right)$, NaOH-P $\left(\mathrm{mg} \mathrm{kg}^{-1}\right)$, HCl-P $\left(\mathrm{mg} \mathrm{kg}^{-1}\right)$ OP $\left(\mathrm{mg} \mathrm{kg}^{-1}\right)$ Sediment TP $\left(\mathrm{mg} \mathrm{kg}^{-1}\right)$ CI-TP $\left.\left(\mu \mathrm{g} \mathrm{L}^{-1}\right)\right)$ in the Wushan core.

\subsection{Sediment phosphorus species}

Total phosphorus (TP) values range from 412 to $1620 \mathrm{mg} \mathrm{kg}^{-1}$ (Fig. 4). Values were relatively low and constant before the middle 1920 s, after which they gradually increased. The highest concentrations were recorded in recent years. The concentrations of $\mathrm{NaOH}-\mathrm{P}$ and OP range from 182-914 $\mathrm{mg} \mathrm{kg}^{-1}$, and $138-426 \mathrm{mg}$ $\mathrm{kg}^{-1}$ respectively. In contrast peak concentrations of HCl-P occur between the middle 1920s and the middle 1950s.

\subsection{Magnetic susceptibility}

$\chi \mathrm{LF}$ values (Fig. 4) increase steadily from 1860 s, reaching a peak from the middle 1920 s to the middle 1950s. After which values decrease gradually to the top of the core.

\subsection{Chironomid assemblages}

A total of 34 chironomid taxa were identified in the core. Within the taxa, Microchironomus tabarui and Propsilocerus akamusi do not occur in the identification guides this paper used. Microchironomus tabarui can be differentiated from other Microchironomus taxa as the 3 outermost lateral teeth of the mentum are not arranged in a distinct cluster and the lateral teeth gradually descend from the first to the sixth. Propsilocerus akamusi can be identified as it has 9-10 pairs of lateral teeth. Three zones were identified using CONISS analysis (Fig. 5). Zone 1: 45-29 cm ( 1860s-the middle 1920 s) is dominated by Paratanytarsus penicillatustype, Polypedilum nubeculosum-type, Microchironomus and Cricotopus intersectus-type. In zone 2a (the middle 1920s-the middle 1950s), these taxa decline as Microchironomus tabarui, Procladius, Propsilocerus akamusi and Tanypus begin to increase. Zone $2 \mathrm{~b}$ (the middle 1950s-2007) shows an almost complete dominance of the same taxa that increase in zone 2a, but with associated decreases and/or local extirpations of many of the other taxa previously present in the lake.

\subsection{Chironomid-inferred water TP}

A chironomid-inferred record of mean annual lake water TP (CI-TP) for the period 1860s - 2007, was calculated for the Wushan Core by applying a WA-PLS 


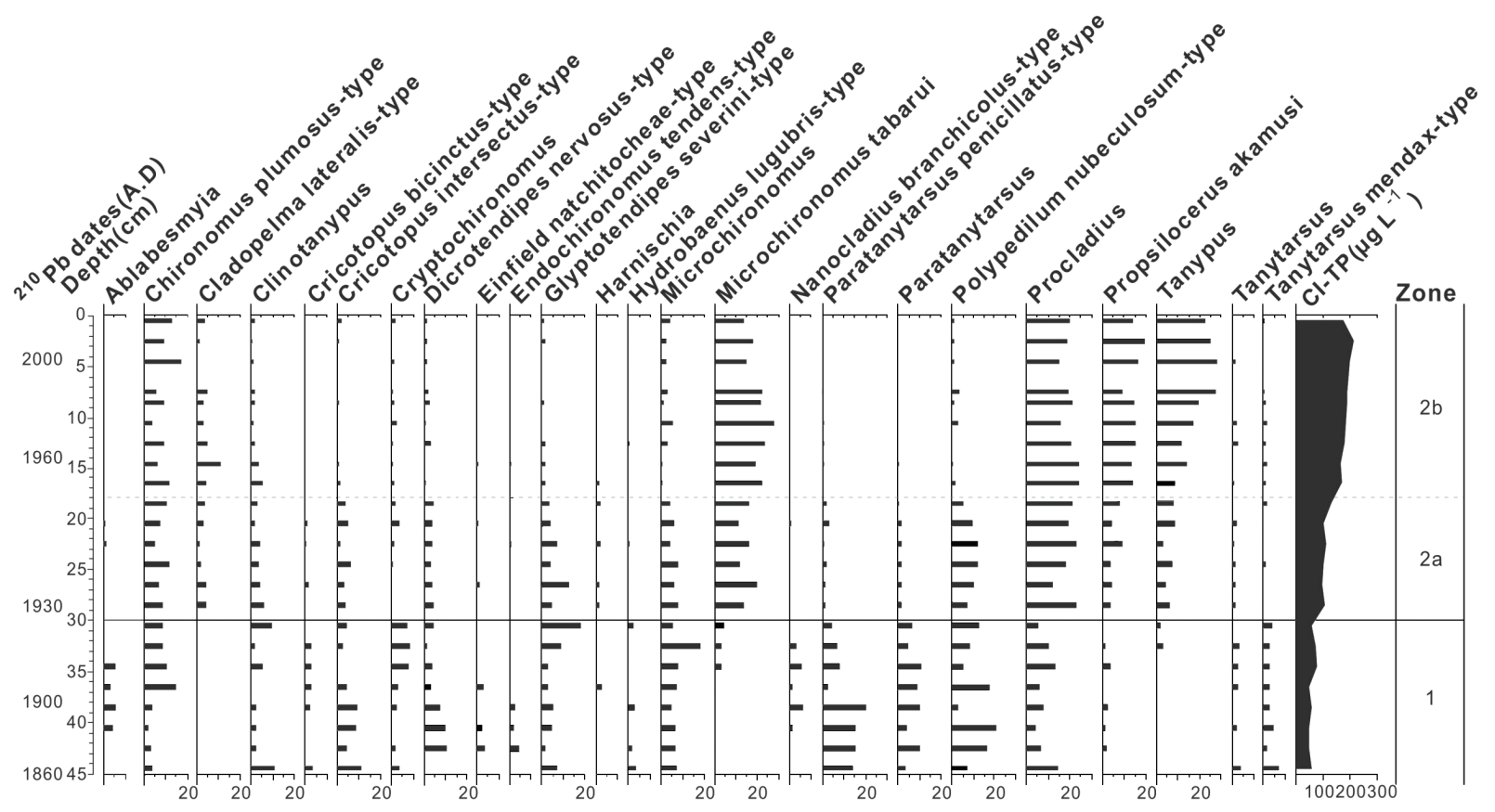

Fig. 5. Selected chironomid taxa in percentage abundance (\%), CI-TP for Lake Wushan, covering the period 1860 s to 2007.

model (Zhang et al. 2006), to the fossil chironomid assemblage data (Fig. 4). CI-TP values are relatively low at the base of the core $\left(50-60 \mu \mathrm{g} \mathrm{L}^{-1} \mathrm{TP}\right)$, rising gradually to $100 \mu \mathrm{g} \mathrm{TP} \mathrm{L}{ }^{-1}$ by the middle 1920 s. CI-TP then remains relatively stable until the middle 1940s, before increasing to $\sim 160 \mu \mathrm{g} \mathrm{L}^{-1} \mathrm{TP}$. After this point values are seen to rise rapidly, reaching $210 \mu \mathrm{g} \mathrm{L} \mathrm{L}^{-1} \mathrm{TP}$ by the top of the core (2007). This CI-TP concentration for the surface sediment sample $\left(210 \mu \mathrm{g} \mathrm{L}^{-1} \mathrm{TP}\right)$ was in good agreement with modern values for total phosphorus concentration in the lake water $\left(207.4 \mu \mathrm{g} \mathrm{\textrm {L } ^ { - 1 }} \mathrm{TP}\right)$ sampled in 2001-2003 (Yang et al. 2008).

\section{DISCUSSION}

Analysis of the multi-proxy data set for Wushan indicates that the lake has experienced significant increased nutrient loading over the last 150 years. Over the last 50 years the situation has become particularly acute, leading to a major shift in lake status from mesotrophic to more eutrophic conditions.

Within the subfossil chironomid record the changing water quality is characterised by a clear shift in fauna commencing around the middle 1920s. Taxa which dominated pre-the middle $1920 \mathrm{~s}$, in zone 1 , such as Paratanytarsus, Dicrotendipes and Polypedilum nubeculosum-type are indicative of relatively clear water conditions with a reasonable macrophyte density and/or species richness from lakes in NW Europe (Davidson et al. 2010; Langdon et al. 2010). Their co-occurrence here, pre-impact and pre-eutrophication, suggest that their general ecologies (in terms of subfossil genera and taxon morphotypes) are similar to the studies from the Palaearctic although further ecological data from Chi- nese lakes would help to confirm this. These taxa, which showed stability from the mid $19^{\text {th }}$ Century to the start of the $20^{\text {th }}$ Century, are either reduced or almost lost completely from the fauna post-the middle 1920s, as taxa such as Microchironomus tabarui, Procladius, Propsilocerus akamusi and Tanypus either increase in concentrations significantly and/or become part of the local fauna for the first time in the current record. Chironomus plumosus-type also increases in abundance around this time and is a well known eutrophic/anoxic indicator (Brooks et al. 2007). This clear change in fauna occurs over a period of $c a 20$ years, indicating that either increased loadings were substantial over this time and/or a threshold was crossed within the lake functioning leading to, for example, a regime shift within the lake ecosystem (cfr. Carpenter 2003). The chironomid data would indicate that this change was accompanied by a decline in macrophyte-dwelling taxa, a phenomenon often associated with increased eutrophication. The CI-TP reconstruction also suggests the lake has become increasingly more productive. Values for CI-TP were relatively low in the late $19^{\text {th }}$ and early $20^{\text {th }}$ Century (50-60 $\left.\mu \mathrm{g} \mathrm{L}^{-1} \mathrm{TP}\right)$. These values are comparable to the diatom-inferred TP concentration from shallow lakes in middle and lower reaches of Yangtze River (Dong et al. 2008; Yang et al. 2008). The CI-TP record shows clear increases in productivity post the middle 1920s and further increases post the middle 1950s. A similar trend is also recorded at Taibai Lake and Longgan Lake, that lie within the same catchment (Yang et al. 2002, 2008; Wu et al. 2008).

Studies suggest that the anthropogenic input of phosphorus from the wastewater contributes primarily 
to the NaOH-P component, whereas HCl-P is derived mainly from the terrestrial sources (Correll 1998; Zhang \& Shan 2008). The contribution of OP can be from either terrestrial or aquatic sources, a proportion of which could be decomposed and released to the water. The increased contribution of NaOH-P and OP since the middle 1920s further supports the inference of an increase in lake productivity over this time.

$\mathrm{C} / \mathrm{N}$ ratios of $8-12$ suggest that submerged macrophytes and/or aquatic algae were the main source of carbon to the lake prior to the early 1900s, which supports the inference from the chironomid data. The decline in values recorded after the middle 1920s points to an increased contribution of algal material (Meyers 1994; Meyers \& Teranes 2001). This is not reflected in the $\delta^{13} \mathrm{C}_{\text {org }}$ record, which trends in the opposite direction, suggesting an increased contribution of terrestrial plant material. This apparent discrepancy may reflect subtle changes in the contribution of organic matter from macrophyte and/or phytoplankton sources accompanied by shifts in the degree of fractionation (Popp et al. 1999; Neumann et al. 2002; Vuorio et al. 2006). A range of palaeolimnological studies have shown that changes in primary productivity do not always yield linear shifts in $\delta^{13} \mathrm{C}$ values (Brenner et al. 1999; Benson et al. 2008). A similar situation has been observed in the sediment record from Lake Taihu in Jiangsu province (Wu et al. 2006).

The changes observed in the sediment core from Lake Wushan are typical of an area experiencing elevated nutrient input from urban and agricultural sources. This interpretation is confirmed by the recent land use history of the area, which highlights several phases of significant anthropogenic activity in the catchment over the time period covered by the core. Widespread deforestation and frequent flooding were commonplace in the catchment before $1950 \mathrm{~s}$, which can be linked to increased erosion of the catchment and an increased flux of terrestrial material into the lake (Wuxue committee for compilation of local chronicles, 1994). After 1949, a series of water conservancy measures were implemented within the Wushan catchment, and the lake was partly drained for agricultural land reclamation during the 1950-70s (Wuxue committee for compilation of local chronicles, 1994). During this time the lake decreased in area from $42.5 \mathrm{~km}^{2}$ to the present $16.1 \mathrm{~km}^{2}$ (Wang \& Dou 1998). The decline in the hydrological storage capacity of the lake, combined with the increased use of chemical fertilizer across the catchment would have significantly increased levels of primary production in the lake. The $\chi \mathrm{LF}$ peak period from the middle 1920s-1950s and a coarsening of particle size combined with a higher HCl-P content in the sediment further supports the inference of an increase in terrestrial sediments to the lake over this period, and increasing TP levels.
The high use of N-P-K fertiliser in the catchment over the last 30 years has had a major impact on the lake system at Wushu and is likely to be responsible, at least in part, for the observed rise in TP. Such an interpretation is supported by the $\delta^{15} \mathrm{~N}$ signature, changes in which would be expect to be in proportion to the quantity of $\mathrm{N}$ fertiliser applied, regardless of the initial signature of fertiliser (Leavitt et al. 2006; Bunting et al. 2007). The abrupt jump in $\delta^{15} \mathrm{~N}$ around 1950 is most likely to be linked to the introduction of chemical fertilisers into the catchment.

\section{CONCLUSIONS}

Analysis of the recent sedimentary record from Lake Wushan clearly indicates that the site has been heavily impacted by anthropogenic activity over the last 150 years. The long-term impact on the lake ecosystem has been a shift in status from mesotrophic to eutrophic. This change is due primarily to the introduction and high use of fertilisers, increased industrial activity and accelerated urbanisation. Based on the CI-TP record, the relatively low water phosphorus concentration (50-60 $\mu \mathrm{g} \mathrm{L}^{-1} \mathrm{TP}$ ) recorded for the lake in the late $19^{\text {th }}$ Century and the early $20^{\text {th }}$ Century suggests this period could be targeted as a likely reference period for future remediation efforts.

\section{ACKNOWLEDGMENT}

We are grateful to Prof. Bin Xue and Prof. Yanhong $\mathrm{Wu}$ for their help on fieldwork, to Mr. Weilan Xia for the ${ }^{210} \mathrm{~Pb}$ date measurement. We are very grateful to Dr. Stefan Engels and two anonymous referees whose comments greatly improved the manuscript. This study was supported by the Knowledge Innovation Program of the Chinese Academy of Sciences (kzcx2-yw-319) and by National Basic Research Program of China (No:2008CB418103).

\section{REFERENCE}

Appleby, P.G. 2001.Chronostratigraphic techniques in recent sediment, In: Last, W.M. \& J. P.Smol (Eds), Trancking environmental change using lake sediments, Volume 1: basin analysis, coring, and chronological techniques. Klauwer Academic Publishers, 171-196.

Appleby, P.G. \& F. Oldfield. 1992. Application of ${ }^{210} \mathrm{~Pb}$ to sedimentation studies. In: Ivanovich, M. \& R.S. Harmon (Ed.), Uranium series disequilibrium. OUP: 731-778.

Benson, E.R., J.M. O'Neil \& W.C. Dennison. 2008. Using the aquatic macrophyte Vallisneria americana (wild celery) as a nutrient bioindicator. Hydrobiologia, 596: 187-196.

Brenner, M., T.J. Whitmore, J.H. Curtis, D.A. Hodell \& C.L. Schelske. 1999. Stable isotope $\left(\delta^{13} \mathrm{C}\right.$ and $\left.\delta^{15} \mathrm{~N}\right)$ signatures of sediment organic matter as indicators of historic lake tropic state. J. Paleolimnol., 22: 205-221.

Brooks, S.J., P.G. Langdon \& O. Heiri. 2007. The identification and use of Palaearctic Chironomidae larvae in palaeoecology. QRA Technical Guide No. 10. Quaternary Research Association, London: 276 pp.

Bunting, L., P.R. Leavitt, C.E. Gibson, E.J. Mcgee \& V.A. Hall. 2007. Degradation of water quality in Lough Neagh, 
Northern Ireland, by diffuse nitrogen flux from a phosphorus-rich catchment. Limnol. Oceanogr., 52: 354-369.

Carpenter, S.C. 2003. Regime shifts in lake ecosystems: pattern and variation. Volume 15 in the Excellence in Ecology Series, Ecology Institute, Oldendorf/Luhe, Germany: $199 \mathrm{pp}$.

Correll, D.L. 1998. The role of phosphorus in the eutrophication of receiving waters: a review. J. Environ. Qual., 27: 261-266.

Davidson, T.A., C.D. Sayer, P.G. Langdon, A. Burgess \& M. Jackson. 2010. Inferring past zooplanktivorous fish and macrophyte density in a shallow lake: application of a new regression tree model. Freshwat. Biol., 55: 584-599.

Dong, X., H. Bennion, R. Battarbee, X. Yang, H. Yang \& E. Liu. 2008. Tracking eutrophication in Taihu Lake using the diatom record: potential and problems. J. Paleolimnol., 40: 413-429.

Engstrom, D.R., S.P. Schottler, P.R. Leavitt \& K.E. Havens. 2006. A reevaluation of the cultural eutrophication of Lake Okeechobee using multiproxy sediment records. Ecol. Appl., 16: 1194-1206.

Evans, M.E. \& F. Heller. 2003. Environmental magnetism principles and applications of enviromagnetics. London Academic Press: 382 pp.

Grimm, E.C. 1987. CONISS: A Fortran 77 program for stratigraphically constrained cluster analysis by the method of incremental sum of squares. Comp. Geosci., 13: 13-35.

Grimm, E.C. 1991. TILIA version 1.11. TILIAGRAPH version 1.18. In Gear, A. (Ed.), A Users Notebook. Illinois State Museum, Springfield, USA.

Hall, R.I. \& J.P. Smol. 1999. Diatoms as indicators of lake eutrophication. Pages 128-168. IN: Stoermer, E.F. \& J.P. Smol (Ed.), The diatoms: applications for the environmental and earth sciences. Cambridge University Press, Cambridge, UK: 128-168.

Jian, Y., J. Wang, G. He, J. Li \& J. Chen. 2001. A comparative study of aquaticplant diversity of Haikou, Taibai and Wushan Lake in Hebei Province of China. Acta Ecologica Sinica, 21: 1815-1824 (in Chinese).

Jordan, P., B. Rippey \& N.J. Anderson. 2001. Modeling diffuse phosphorus loads from land to freshwater using the sedimentary record. Environmental Science and Technology, 35: 815-819.

Juggins, S. 2003. C2 user guide: software for ecological and palaeoecological data analysis and visualisation. University of Newcastle, Newcastle upon Tyne, Britain.

Langdon, P.G., Z. Ruiz, S. Wynne, C.D. Sayer \& T.A. Davidson. 2010. Ecological influences on larval chironomid communities in shallow lakes: implications for palaeolimnological interpretations. Freshwat. Biol., 55: 531-545.

Leavitt, P.R., C.S. Brock, C. Ebel \& A. Patoine. 2006. Landscape-scale effects of urban nitrogen on a chain of freshwater lakes in central North America. Limnol. Oceanogr., 51: 2262-2277.

Liu, J. \& J. Diamond. 2005. China's environment in a globalizing world. Nature, 435: 1179-1186.

Meyers, P.A. 1994. Preservation of source identification of sedimentary organic matter during and after deposition. Chem. Geol., 144: 289-302.

Meyers, P.A. \& J.L. Teranes. 2001. Sediment organic matter. In: Last, W.M. \& J.P. Smol (Ed.), Tracking environmental changes using lake sediment, vol 2: physical and geochemical methods. Klauwer Academic Publishers: 239-270.

Neumann, T., A. Stogbauer, E. Walpersdorf, D. Stuben \& H. Kunzendorf. 2002. Stable isotopes in recent sediments of Lake Arendsee, NE Germany: response to eutrophication and remediation measures. Palaeogeogr. Palaeoclimateol. Palaeoecol., 178: 75-90.

Oliver, D.R. \& M.E. Roussel. 1983. The Insects and Arachnids of Canada. Part 11. The Genera of Larval Midges of Canada. Diptera: Chironomidae. Agric. Can. Publ., 1746: 263 pp.

Popp, B.N., T. Trull, F. Kenig, S.G. Wakeham, T.M. Rust, B. Tilbrook, F.B. Griffiths, S.W. Wright, H.J. Marchant, R.R. Bidigare \& E.A. Laws. 1999. Controls on the carbon isotopic composition of southern ocean phytoplankton. Global Biogeochem. Cycles, 13: 827-843.

Qin, B.Q. \& G.W. Zhu. 2006. The nutrient forms, cycling and exchange flux in the sediment and overlying water system in lakes from the middle and lower reaches of Yangtze River. Science in China (Series D), 49: 1-13.

Ramstack, J.M., S.C. Fritz \& D.R. Engstrom. 2004. Twentieth century water quality trends in Minnesota lakes compared with presettlement variability. Can. J. Fish. aquat. Sci., 61: $561-576$

Rieradevall, M. \& S.J. Brooks. 2001. An identification guide to subfossil Tanypodinae larvae (Insecta: Diptera: Chironomidae) based on cephalic setation. J. Paleolimnol., 25: 81-99.

Ruban, V., J.F. López-Sánchez, P. Pardo, G. Rauret, H. Muntau \& P.H. Quevauviller. 2001. Development of a harmonised phosphorus extraction procedure and certification of a sediment reference material. J. Environ. Monit., 3: 121-125.

Smol, J.P. 2002. Pollution of lakes and rivers: a paleoenvironmental perspective. Oxford University Press, New York, USA: $280 \mathrm{pp}$.

Vuorio, K., M. Meili \& J. Sarvala. 2006. Taxon-specific variation in the stable isotopic signatures $\left(\delta^{13} \mathrm{C}\right.$ and $\left.\delta^{15} \mathrm{~N}\right)$ of lake phytoplankton. Freshwat. Biol., 51: 807-822.

Wang, S. \& H. Dou. 1998. Lakes in China. Science Press, Beijing: 398-502 (in Chinese).

Wiederholm, T. 1983. Chironomidae of the Holarctic Region. Keys and diagnoses. Part I. Larvae. Entomologica Scandinavica Supplement: 457 pp.

Wu, J.L., L. Lin, M.K. Gagan, G.H. Schlese \& S.M. Wang. 2006. Organic matter stable isotope $\left(\delta^{13} \mathrm{C}, \delta^{15} \mathrm{~N}\right)$ response to historical eutrophication of Lake Taihu, China. Hydrobiologia, 563: 19-29.

Wu, Y., A. Lücke \& S. Wang. 2008. Assessment of nutrient sources and paleoproductivity during the past century in Longgan Lake, middle reaches of the Yangtze River, China. J. Paleolimnol., 39: 451-462.

Wuxue committee for compilation of local chronicles. 1994. Guangji County local chronicles. The Publishing House of the Chinese Dictionary.

Yang, X.D., N.J. Anderson, X. Dong \& J. Shen. 2008. Surface sediment diatom assemblages and epilimnetic total phosphorus in large, shallow lakes of the Yangtze floodplain: their relationships and implications for assessing longterm eutrophication. Freshwat. Biol., 53: 1273-1290.

Yang, X., S. Wang, J. Shen, Y. Zhu, Z. Zhang \& Y. Wu. 2002. Lacustrine environment responses to human activities in the past 300 years in Longgan Lake catchment, southeast China. Science in China (Series D)., 45: 709-718.

Zhang, E.L., A. Bedford, J. Richard, J. Shen, S.M. Wang \& H.Q. Tang. 2006. A subfossil chironomid-total phosphorus inference model from the middle and lower reaches of Yangtze River lakes. Chinese Science Bulletin, 51(17): 2125-2132.

Zhang, H \& B. Shan. 2008. Historical distribution and partitioning of phosphorus in sediments in an agricultural watershed in the Yangtze-Huaihe Region, China. Environ. Sci. Technol., 42: 2328-2333. 